\title{
Discussion: Commentary: 3D printing set to transform the construction industry
}

Paul Mullett BEng (Hons), PhD, GMICE

Assistant Professor in Civil Engineering and Environmental Materials, Department of Civil and Environmental Engineering, Brunel University London, London, UK

Seyed Ghaffar BEng (Hons), CEng, FICE, FCIArb, PSE Director - Head of Engineering and Technology (MENA) Robert Bird Group, Member of the Surbana Jurong Group, Dubai, UAE
Paul Perry BSc (Hons), CEng, MIStructE, MICE, MHKIE Associate Director, Hewson Consulting Engineers, Guildford, UK

\section{Contribution by Paul Perry}

The commentary by Mullett and Ghaffar (2018) suggests that three-dimensional (3D) printing will change the way structures and buildings are constructed and goes on to describe a 'concrete' example as being the most relevant for large-scale construction.

The approach would also be applicable for steel castings, undertaken by specialist subcontractors within the construction industry, with the same aim of incorporating geometric complexity within the overall structure of the structural scheme. Using such digital engineering to deliver design quicker, safer and more effectively assumes that the construction will flow!

In 2001-2002, Robert Benaim and Associates was appointed as structural engineer for the refurbishment of a department store at 103-113 Regent Street, London, originally completed in 1926 to designs by architects P. J. Westwood \& Emberton with Sir Reginald Blomfield as architect for the external elevations (Paterson and Perry, 2002). The scheme included the feasibility, detailed design and construction support for the installation of 'scenic' lifts in the new 'opened-up' floors within the building. The contributor's range of structural solutions for the lift scheme included steel castings to act as diaphragms between the vertical members of the lift structure. This was eventually chosen as the scheme to be designed and constructed (Figure 1).

The steel casting was procured using a particular specification and engineer's design intent detailed sketch. Clearly, the availability of $3 \mathrm{D}$ printing at that time would have assisted in the scheme development, detailed design and the steel casting process, especially with trials of various shapes and improvement in the casting process.

Looking back on the lessons learnt then and applying them to the suggestions given in the commentary, the contributor would suggest that, in order to assist $3 \mathrm{D}$ printing being more commonplace in the industry, there ought to be:

a standard template for the structural engineer's design intent approach, including guidance on how to show through building information modelling (BIM)

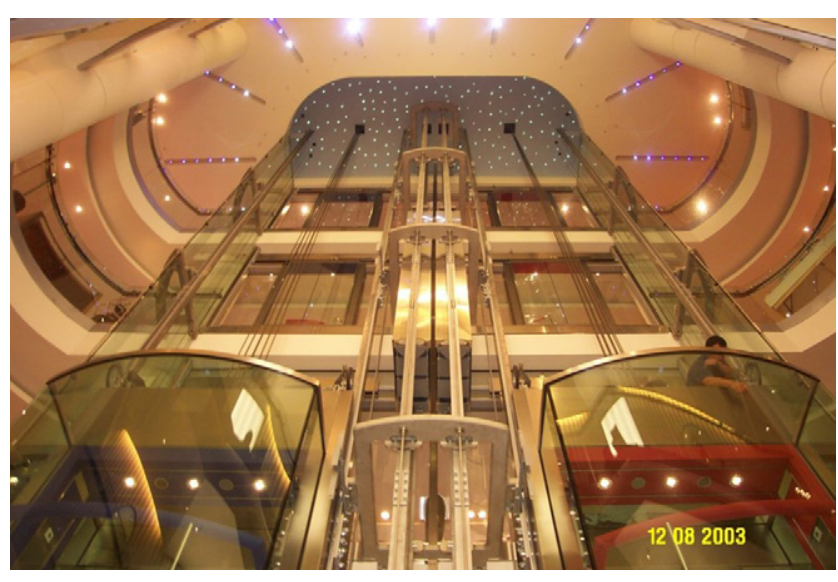

Figure 1. 103-113 Regent Street, London - completed scheme showing cast steel diaphragms at each floor

- a standard approach with regard to specification, maybe even a specific section within the National Building Specification

- expectations from main contractors/specialist subcontractors, such that $3 \mathrm{D}$ printing with steel casting (and other materials such as concrete as described in the commentary) is adopted appropriately and correctly incorporated within tender sums

- clarity on the responsibility for updating the BIM, from the structural engineer's design intent to the $3 \mathrm{D}$ printed creation of the main contractor/specialist subcontractor, to reflect what has been constructed.

I would be interested in the authors' comments.

\section{Authors' reply}

We would like to thank the contributor for his response to the commentary. As pointed out in the commentary, in recent years, the construction industry's interest has gravitated towards the exploration of additive manufacturing as a largescale construction alternative, replacing traditional blockwork or concrete construction for typically low-rise construction. 
While the technological achievements of additive manufacturing in construction are encouraging to date, with numerous proof-of-concepts delivered across the globe, the technology has yet to demonstrate real value and find its way into the industry's toolkit (Mullett, 2020).

The contributor is correct to point out that there are many other potential uses for additive manufacturing in the construction sector. Indeed, additive manufacturing is not one technology but several, which have collective potential across a broad range of applications, including structural components, facades, mechanical and electrical fittings and, of course, finishes/fittings.

The example provided by the contributor - the use of $3 \mathrm{D}$ printing as an alternative to bespoke steel castings - is one type of application where additive manufacturing could provide real value. Indeed, this is an area where opportunities are already being explored alongside complementary technologies such as topology optimisation (Galjaard et al., 2014).

The issue of standardised specifications, templates, design guidance and, of course, regulation is one that must be high on the agenda of additive manufacturing champions in the construction industry if it is to gain greater acceptance. While there is some generic guidance (ISO, 2015) and some specific ISO/ASTM standards are available, further specific guidance is pending the outcome of the ISO/TC 261 working groups and similarly the American Concrete Institute's ACI 564 committee. There is no doubt that regulatory guidance for the construction industry is lagging behind developments and demand.

The authors would also urge greater transparency from industry on technical, practical and costing matters to inform and educate stakeholders to better understand the risks and opportunities additive manufacturing presents.

\section{REFERENCES}

Galjaard S, Hofman S and Ren S (2014) New opportunities to optimize structural designs in metal by using additive manufacturing. In Advances in Architectural Geometry 2014 (Block P, Knippers J, Mitra NJ and Wang W (eds)). Springer International Publishing, Cham, Switzerland, pp. 79-93.

ISO (International Standards Organisation) (2015) ISO/ASTM 52900:2015: Additive manufacturing - general principles terminology. ISO, Geneva, Switzerland.

Mullett P (2020) 3D printing in construction: Where is the value? Building, 13 March. See https://www.building.co. $\mathrm{uk} /$ comment/3d-printing-in-construction-where-is-thevalue/5104640.article (accessed 11/02/2021).

Mullett P and Ghaffar S (2018) Commentary: 3D printing set to transform the construction industry. Proceedings of the Institution of Civil Engineers - Structures and Buildings 171(10): 737-738, https://doi.org/10.1680/jstbu.18.00136.

Paterson J and Perry PJG (2002) A systemic approach to refurbishment. The Structural Engineer 80(9): 14-16. 